This is the version of the article accepted for publication in Annual Review of Law and Social Science, 17

https://doi.org/10.1146/annurev-lawsocsci-010421-014915

Re-use is subject to the publisher's terms and conditions

Accepted version downloaded from SOAS Research Online: http://eprints.soas.ac.uk/35175

\title{
WATER SECURITY AND INTERNATIONAL LAW
}

\author{
Philippe Cullet ${ }^{1}$, Lovleen Bhullar ${ }^{2}$ \& Sujith Koonan ${ }^{3}$
}

Forthcoming in: 17 Annual Review of Law and Social Science (2021)

\section{INTRODUCTION}

Water security has emerged as a significant concern at the international level over the past couple of decades. This is related to the broadening of the securitization discourse in the wake of the Cold War (Gleick 1993: 81). A progressive understanding that (military) security cannot be ensured without taking into account a broader array of factors led to the development of environmental security and human security (Brunnée \& Toope 1997). Over time, other concerns such as water security, food security, energy security and climate security were added to this list (Grobicki 2016). In other words, while security as such remains a buzzword in academic and policy circles, it is now associated with a diverse range of issues under the heading 'human security' that are not directly linked to the orthodox securitization discourse.

There is an intimate link between international law and water security. Water insecurity is, for instance, regarded as a concern for international peace and security. Thus, international water law, in particular the 1997 Convention on the Law of the Non-navigational Uses of International Watercourses [hereafter 1997 UN Watercourses Convention], which constitutes the most important legal instrument in the field, is concerned in large part with fostering cooperation and avoiding conflicts. Both these aspects are at the heart of the water security discourse. Other instruments such as the 1992 Convention on the Protection and Use of Transboundary Watercourses and International Lakes [hereafter 1992 Helsinki Watercourses Convention] are regional in scope, and the many other water agreements tend to be watercourse-specific or river basin-specific. This explains why water security cannot be examined solely through the lens of international water law, whose scope is limited. Other water security-related concerns are addressed in several other branches of international law, such as international environmental law, international human rights law and international humanitarian law. In some cases, such as the human right to water, there is no binding recognition of the right yet, whose recognition is limited to UN General Assembly resolutions (United Nations 2019).

This review is divided in three main sections. The first section examines the understanding of water security in the broader context in which the concept has emerged and has been used. The second section addresses the relationship between water security and international law, and the former's multi-scalar dimensions. The third section considers the contributions of the literature relating to international water law and other branches of international law to framing and developing the concept of water security.

1 School of Law, SOAS University of London, London WC1H 0XG, United Kingdom; Centre for Policy Research, New Delhi 110021, India; email: pcullet@soas.ac.uk

2 Birmingham Law School, University of Birmingham, Birmingham B15 2TT, United Kingdom; email: 1.bhullar@bham.ac.uk

3 Campus Law Centre, Faculty of Law, University of Delhi, New Delhi 110007, India; email: sk@clc.du.ac.in 


\section{The Concept of Water Security in its Global Context}

The securitization process elevates an issue to the top of the agenda owing to the perceived existential threat it poses and the consequent need for extraordinary and urgent measures to deal with the issue (Magsig 2011: 328). Securitization of any issue invariably induces interventions including legal interventions or at least a reconceptualization of the issue followed by renewed legal interventions. In the specific context of water, emergence of the security discourse led to a fresh look at international law in general and international water law in particular in terms of its potential and limitations in achieving water security goals. At the same time, the international law literature does not provide a clear analysis of the concept of water security and thus leaves scholars and policy makers to turn to other disciplines for conceptual clarity. This part of the paper looks at the emergence of the water security discourse and its conceptual boundaries as expounded in the academic literature.

\section{A. Securitization OF WATER}

Security as a subject matter of academic study was understood, for long, in a narrow sense of military security, which follows a state-centric approach. The concept had a limited focus on security of the political system from external military interventions. The near exclusive focus on military security eventually gave way to the expansion of the security discourse to include a range of non-military, non-state centric, sector-focused security discourses such as water security, food security, energy security and climate security (Cook \& Bakker 2012: 100).

According to Magsig, the 'deepening' and 'widening' of the security discourse 'led to the notions of collective and sustainable security, which try to pave the way towards a mutual understanding that security can no longer be regarded as a zero-sum game between states' (Magsig 2011: 329-30; see also Magsig 2020). In other words, expansion of the security discourse to 'human security' paved the way for conceptualization of security issues even at the level of individuals and communities (Allouche, Nicol \& Mehta 2011: 156-7). Sultana \& Loftus (2020: 6) also underline the development of the water security discourse from a statecentric focus to a 'human security framing (in which referent shifts from nation-state to the individual and community)' and 'ecological security in which the biosphere becomes the principal referent object to be secured'. Thus, expansion of the security discourse led to an important substantive change in the nature of the discourse, that is, the focus has been expanded to individuals, communities and the environment as away from the erstwhile state-centric military focus.

The justification for the securitization of water is based on the diminishing availability, deteriorating quality and uneven distribution of the resource in space and time and the consequent conflict between different users and uses at both the domestic and international levels. These concerns are likely to be further exacerbated with global environmental problems such as climate change and may pose considerable security problems at the global level (Eckstein 2009: 430). As a result, there is a call for giving special treatment to water as a key component of 'ultimate security' (Magsig 2011: 331). The notion of scarcity is indeed central and water security has been seen as a means of refining this blunt notion and conceptualizing the complex dynamics of water systems (Mahayni 2013: 37).

Water security does not seem to have clearly laid down conceptual boundaries. Different studies highlight different elements with varying degrees of emphasis and combinations depending upon the disciplines (e.g., law, development studies) and the scale of the study (local, regional and international): 
First, from an individual's point of view, water security denotes meeting certain standards related to availability, affordability and quality. This aspect is more prominent at the local level. It emphasizes a human rights approach within states and underlines the right of all people to enjoy secure access to adequate supplies of drinking water (Wouters 2010: 5-6; Appelgren \& Klohn 1997: 91). While the individual aspects of water security are important for social and economic development, they are equally important from the point of view of prevention and resolution of inter- and intra-sectoral water conflicts at the local level (Cullet, Bhullar \& Koonan 2015).

Second, at the regional and international level, a major focus is on military-related threats, reflecting a more traditional security approach where water is conceived mainly as a potential source of conflict between states and therefore the focus is mainly on the limited goal of ensuring cooperation between different riparian countries (Wouters 2005: 168; Honkonen 2017: 5-6). Thus, river-basin agreements generally tend to focus on quantitative sharing of water and dispute settlement mechanisms (Iyer 1999; Zawahri 2008).

This dichotomy concerning the scope of water security at different levels may be seen as the underlying logic of international legal responses. The aspect of individual water security is part of international human rights law, and the collective security dimension is a key subject matter of regional and international water agreements (Honkonen 2017: 5).

Third, environmental aspects are highlighted often in tandem with the above-mentioned dimensions. For instance, Cook \& Bakker (2012: 100) refer to an integrated definition of water security adopted at the Water World Forum 2000 that focuses on access and affordability of water as well as human needs and ecological health.

The range of definitions of 'water security' and their reviews by scholars help us identify four important elements with legal connotations (Wouters, Vinogradov \& Magsig 2009: 106; Cook \& Bakker 2012: 97; Honkonen 2017: 5-6). The first is availability, which focuses on controlled supply of quality and safe water. The second is access, which revolves around enforceable rights to water for a range of stakeholders. The third addresses conflicts where competing uses occur, for which a mechanism to avoid and/or address disputes is needed. While these three elements are human-centric in nature, a fourth element that captures the environmental dimensions of water security could be added to this understanding to bring eco-centric aspects to water security.

The focus of the water security discourse on goals such as securing access to water for individuals, inter-state cooperation to prevent international/regional water conflicts and achieving environmental sustainability is regarded as reductionist in terms of its nature and scope. It is suggested that water security should be redefined and viewed as 'securing water relations that recognize the wider relations through which water shapes people's lives and contributes to human flourishing and well-being' as opposed to 'securing water as a thing and end in itself (as H2O)' (Jepson, Wutich \& Harris 2020: 85-6). The suggestion is based on the need to take into consideration the multiple dimensions and roles of water such as its social, economic and cultural values, rather than reducing water to a resource that is simply to be used or managed for various purposes.

\section{B. INTEGRATIONIST AND UNIFYING APPROACHES}

Water security discourses advance mainly two approaches based on the relative position of water security in comparison with other paradigms or goals. First, the integrationist method recognizes the close linkages or 'nexus' between water and other challenges related to food, environment and energy. This method arguably originated at the World Economic Forum 2008 and eventually became a central theme of the sustainable development discourse. It underlines 
the importance of adopting integrated management of the different sectors concerned, in opposition to sectoral management (Allouche, Middleton \& Gyawali 2019: 131; Weinthal, Vengosh \& Neville 2018: 201).

These close inter-linkages led Wouters (2010: 3) to call 'water-food-energy' a security triad. This security triad emphasizes water as a significant input in the production of both energy and food (Keulertz et al. 2018: 168). Since over 90 per cent of the world's energy production is water intensive, it may compromise the availability of water. At the same time, the generation of energy may pollute water resources and thus reduce available water supply (Maduekwe \& Young 2018: 283). In the case of the nexus between water and food, water is an important input to agriculture on one hand, and agriculture and related activities may cause water pollution on the other. The scenario gets further complicated with the use of treated or untreated wastewater for agriculture (Keulertz et al. 2018: 172).

Water security has also been projected as one of the paradigms to achieve the ultimate objective of integrated management of resources and the environment. This ultimate objective is framed in terms of certain principles (equity, efficiency and sustainability) and water security is projected as one of the means, together with other dominant paradigms such as Integrated Water Resource Management (IWRM) to achieve it (McDonnell 2008: 142; Cook \& Bakker 2012: 100; Gerlak \& Mukhtarov 2015).

The debate around the nexus is, thus, based on water security as an independent goal versus water security as an instrument for achieving the ultimate goal of food security or energy security. At the same time, it is problematic to view the nexus only from a cause-effect relationship because the nexus is also a political process characterized by the interplay of multiple actors and powers and the potential scope for a hegemonic narrative overpowering the discourse (Allouche, Middleton \& Gyawali 2019: 3, 15).

The second method emphasizes inter-linkages but seeks to project a unifying dominant paradigm. The multi-dimensional linkages that water has with almost all other social, economic and political issues are used as a basis to project water security as the central focus for legal and/or legal interferences. Achieving water security is also projected as an effective way to address a range of social, economic and political crises that the world faces. Thus, Larson (2020: 1) proposes a unified social policy theory and argues that "perhaps the first step in solving the wicked problems of terrorism, racism, climate change, global pandemics, mass immigration, and a host of other challenges is the same: We should reform our laws, policies, and priorities to achieve global water security'. He further argues that 'prioritizing solving one problem - water insecurity — may be the best place to start solving all our problems' (Larson 2020: 1).

The role that water security plays or can play in addressing a number of crises humanity faces today is also used to pitch it against another unifying paradigm in contemporary times, namely climate change. Larson (2017: 140-1) argues that 'climate change should be deemphasized and indeed replaced as a policy paradigm' by a new paradigm for natural resource law and policy centered on 'water security'. He identifies mainly two shortcomings of the existing paradigm based on climate change-it is incomplete and ineffective. The argument advanced is that laypersons do not understand climate change as a pressing problem or they are unable to comprehend it. It is also argued that this paradigm is inadequate because climate change is not the most pressing natural resource problem people face; instead, pressing problems that people face are related to food, water and energy (Larson 2017: 140-1).

In international water law, the nexus is discussed, for instance, in the context of the 1992 Helsinki Watercourses Convention. Here, the nexus approach is centered on procedural 
features including participatory processes, knowledge mobilization, sound scientific analysis and capacity building (Belinskij 2015: 5399). There is a need to go beyond this approach given that international water law does not include any restrictions yet, for instance, when different water needs must be reconciled (Belinskij 2015: 5411-2). More broadly, in a context where some elements of the nexus such as energy security and water security can conflict with each other, it is necessary for the literature to engage more directly with the interactions between international climate law, international water law, and international energy law (Boute 2016: $372,376)$.

\section{International LaW Dimensions of Water Security}

There is a cause-and-effect relationship between water (in)security and international law. On one hand, water insecurity may lead to disputes among countries that are the subject of international law. On the other, international law is concerned with issues such as climate change and armed conflict, which may cause water insecurity. This section highlights the relationship between water security and international law including the former's multi-scalar dimensions.

\section{A. RELATIONSHIP BETWEEN WATER SECURITY AND INTERNATIONAL LAW}

There are different perspectives on the relationship between water security and international law. Explanations for the focus on water security at the international level are that water security challenges are most evident here (Magsig 2009: 61) and the legal response has been particularly pronounced at this level (Wouters, Vinogradov \& Magsig 2009: 98). Magsig (2009: 61) links the scale of the water security challenge at the international level to the number of transboundary/shared watercourses covering a large proportion of the global land mass, as well as population, and also observes that international watercourses entail a complex element of geopolitical risk. According to Leb \& Wouters (2013: 26), 'the achievement of water security revolves around resource management objectives and evokes a range of environmental, economic, and social equity considerations best addressed jointly among the nation-states sharing the resource'. The ambition of the legal response at the international level is questionable including the relative weight attached to the different objectives and considerations that underpin the achievement of water security. Further, water security challenges are also experienced at the individual, local and regional levels, and recent years have witnessed growing interest in examining legal responses at these different levels.

As discussed above, the widening and deepening of the traditional notion of (military) security led to the emergence of the concept of water security. Yet, terms such as 'conflict', 'tension' and 'threat' continue to serve as the starting point for discussions of water (in)security and legal responses. The global water crisis (Magsig 2011: 332) or water conflicts (Magsig 2009: 62) threaten 'international peace and security', one of the objectives of the United Nations. According to Wouters, Vinogradov \& Magsig (2009: 119), 'one of the most important functions of international law is to prevent, manage, and resolve actual or potential conflicts peacefully through the use of available dispute settlement mechanisms and techniques'. Unsurprisingly then, the contribution of international law to ensuring water security is viewed primarily through the lens of prevention or settlement of disputes. International law scholars view the core elements introduced above, namely availability, access and conflict (Wouters, Vinogradov \& Magsig 2009: 106) as core elements that could help, through the normative 
strength of international law, in maintaining 'international peace and security' (Magsig 2011: 333). Given the design and status of implementation of some of the key international instruments, most scholars do not consider issues surrounding the effectiveness of dispute resolution at the international level (but see Magsig 2020: 50). This state-of-affairs provides another reason for greater engagement with the multi-level dimensions of water security.

Another important focus of international law literature is to recognize the constraints of the traditional state-centric approach with its emphasis on state sovereignty. Magsig (2017: 389) notes that international environmental governance in general, and transboundary water management in particular, have long been dominated by the either/or debate on sovereignty versus the joint management of natural resources'. However, the literature does not suggest reformulation of the dominant traditional approach. Instead, the general obligation to cooperate in international law remains the frame of reference in the quest for suitable concepts although it is articulated in different ways. Magsig (2020: 52) emphasizes the concept of cooperative sovereignty, which views sovereignty as interdependence rather than independence. The concept of hydrosolidarity is viewed as 'less sovereignty-invasive' as it is 'founded on the ideas of collective action, interdependence, and a community-of-interests approach' (Wouters, Vinogradov \& Magsig 2009: 127-128; see also Honkonen 2017).

The inclusion of water security debates in international law requires a non-traditional approach mainly because several of the most important developments have taken place in forums that are not led exclusively by states, as has been the case in all United Nations-led initiatives. There was no specific institution within the United Nations leading on water by the early 1990s. The emerging discourse on water security thus found its feet in some of the new mixed governance bodies that have emerged over the past three decades and have been particularly influential in the water sector. This is, for instance, the case of the World Water Council that organizes the World Water Forum. The World Water Council is in legal terms an association under French law but it draws its membership from a variety of non-state and state-led institutions that are influential in the water sector. The World Water Forum is not an international conference in the traditional sense but it includes a ministerial segment that usually adopts a final ministerial declaration that has had immense influence on the development of water policy over the past couple of decades. It is thus not surprising to find that the literature refers to the definition of water security developed in that context as an authoritative definition (World Water Forum 2000).

The resulting legal framework concerning water security at the international level is consequently of mixed nature. It includes a few treaties that concern water directly such as the 1997 UN Watercourses Convention or indirectly such as the 1971 Convention on Wetlands of International Importance Especially as Waterfowl Habitat. It also includes various non-binding instruments, such as the ministerial declaration of the World Water Forum 2000 that focused on water security.

The link between international law and water security is obvious. However, the 'absence of international law in much of the water security debate' has been identified as a factor limiting the 'potential penetrating power of the concept' (Magsig 2020: 45). There exists a perception in the literature that inclusion of international law dimensions in water security debates will legitimize or strengthen the water security discourse. At the same time, there are a few instances where international legal instruments have explicitly used the concept of water security. The Nile Basin Initiative, which introduced the 'non-legal concept of 'water security' that would, practically, mean anything a riparian country wanted it to mean' is seen both as an ingenious solution to the specific problems facing the negotiating states and as the source of potential further disputes (Mekonnen 2010: 430). While there appears to be a strong case for the 
inclusion of international law dimensions in water security debates, there is no clarity on how that relationship is to be operationalized in international agreements. At a broad level, this is related to the potential of international law to contribute to water security goals.

\section{B. INTERNATIONAL LAW AND MULTI-SCALAR DIMENSIONS OF WATER SECURITY}

Unsurprisingly, international law scholars focus first and foremost on the international dimensions of water security. At the same time, they recognize the multi-scalar dimensions or the individual, local, national and regional levels of water security (Wouters, Vinogradov \& Magsig 2009: 97-8; Magsig 2009: 61; see also Appelgren \& Klohn 1997: 91). Lê Phan and Winkler (2016: 295) focus on individual water security, which forms part of water security at the country level but even they acknowledge that water security can be analyzed with regard to multiple levels.

This confirms that it is impossible to ignore the multi-scalar dimensions of water security as water (in)security leads to tensions or conflicts over the control of or access to water resources at different levels and threatens global/international security (Magsig 2009: 61, 62). Armed conflict or interventions may also be used as a bargaining tactics for water security (Daoudy 2008: 91). Expressed differently, '[t]ackling global water security is a highly complex challenge with multilevel and polycentric forces that need to be taken into account' (Magsig 2009: 61). Magsig (2009: 67) shows how the multi-scalar dimensions of water security are reflected in its framing as a collective security issue (see also Magsig 2020: 51). He refers to Scholtz (2009: 162) and notes:

Unsustainable management of freshwater resource is not only a direct threat to the state itself but also to other states - even outside the basin, due to the interconnectedness of the globalized world and the role water plays in linking the various emerging crises. No longer can water be seen as a national security issue, since the most fundamental common value is under threat - the survival of humankind (Magsig 2009: 67).

Further, while water management is a local issue - with policies being implemented at the local, sub-basin or catchment level - several aspects, like the 'right to water' or principles of non-navigational use of international watercourses, are debated in the global arena. This clearly points to the dynamics between the different scales, and the necessity of international water law to act as an interface between those layers (Rieu-Clarke 2010).

The multi-scalar dimensions of water security are also reflected in the relationship between international law and domestic law relating to water security. In this context, Magsig (2009: 67) observes that the 'effectiveness of certain international rules and obligations heavily depend on supporting domestic norms (and vice versa)'. Overall, water security is a multiscalar issue that requires responses at different scales with adequate consideration of their interconnectedness. The challenge for international law scholarship is how to move beyond recognition to active consideration of the multi-scalar dimensions of water security.

\section{Sectoral Dimensions}

The concept of water security is addressed mostly in the literature on international water law. This would be the most logical approach if international water law was comprehensive and it addressed the various dimensions of water security. However, this is not the case. As a result, an understanding of water security from an international law perspective also requires an 
examination of the concept and debates centered around the concept in other branches of international law with a significant focus on water, such as international environmental law and international human rights law.

\section{A. INTERNATIONAL WATER LAW}

Water security has been considered through the prism of international water law, whose core content revolves around regulating the behavior of states concerning transboundary watercourses. This is often examined through the lens of availability, access, and conflict. Magsig (2015: 200) goes as far as saying that ' $[\mathrm{t}]$ he availability of, and access to, freshwater resources is one of the most challenging global security concerns of the twenty-first century'. The water security discourse can prove very useful in understanding the issues arising between states sharing a watercourse in a context where transboundary watercourses are often crucial for the realization of the right to water of riparian communities, for livelihoods and industrial activities. Achieving water security at the national level is thus often related to the management of transboundary rivers on an equitable basis that satisfies all the upstream and downstream riparian states.

As such, water security is a relatively recent concept, but it was latent in the evolution of international water law. The key principles of international water law reflect and promote security thinking, although they are not referred to explicitly as principles of water security (Kuokkanen 2017: 2). In this sense, international water law can contribute to water security in helping 'build trust among users and thus strengthen management institutions' (Tarlock 2008: 728). More specifically, international water law is seen as a useful tool in promoting water security since it defines legal rights and obligations regarding water use, provides tools for ensuring the continuous integrity of the regime including dispute prevention and settlement, and allows for modification of the existing regime in order to be able to accommodate change (Magsig 2015: 32; Wouters 2010: 12). One of the specific perceived contributions of international law to water security is a better outcome of negotiated watercourse-related dispute settlement (Grey \& Garrick 2013: 37). These dimensions have been addressed in case law spanning several decades. This includes diverse interventions, such as the concept of 'community of interest' put forward nearly a century ago (Permanent Court of International Justice 1929) and the much more recent strengthening of the framework concerning the need to conduct an environmental impact assessment in the context of water infrastructure (International Court of Justice 2010).

International water law literature also engages directly with the principle of equitable and reasonable use, which is the main principle of water allocation in international law. It is quite general and requires upstream and downstream states to compromise on their absolute claims to control over the part of the watercourse falling under their territory. This is best secured in states with sound governments and governance. Yet, even though many developed countries have stable governments in place and work towards sound governance, they still face ongoing challenges in meeting their water security imperatives. In this context, Wouters (2005: 176) argues that the rules of international water law, including in particular the 1997 UN Watercourses Convention, provide a solid foundation upon which to develop cooperative arrangements to meet the goal of water security. The core principle of equitable and reasonable use speaks more broadly to an understanding that equity, reasonableness, fairness, and sustainability are enshrined in the key principles of international water law (Wouters, Vinogradov \& Magsig 2009: 98). 
The importance of international water law in contributing to water security is further argued on the basis of its normative strength. The idea of community is, for instance, reflected in the idea of 'normative security' advanced by Ziganshina (2014: 216-7). Here, riparian countries engage in cooperation because they believe in the principle of cooperation as deriving from international law. The basis of cooperation is not necessarily common interests, such as the fact that riparian countries share a common river or an aquifer. Rather this notion of normative community implies 'a sense of connection arising from transparent, discursive and integrative interactions between different actors within and across countries through and about the law' (Ziganshina 2014: 216-7). She underlines that the idea of cooperation on the basis of common interest is 'unsafe' because 'interests are ever-changing' (Ziganshina 2014: 216). In other words, the idea of 'normative community' highlights the potential of international (water) law in facilitating the formation of a 'community' on the basis of the normative strength of international law rather than any other material common interests.

The centrality of the principle of equitable and reasonable use in international water law has also proved to be a constraining factor in broadening debates around water because it has allowed state sovereignty to retain its central position (Magsig 2009: 68; Magsig 2015: 64). This can be explained in part by the fact that water has for long been regarded as a national security issue, leading to an overemphasis on self-interest (Magsig 2015: 45). Such reliance on sovereignty is not unusual in public international law but it is particularly unwelcome in the context of watercourses where states cannot effectively control water flows. It is thus surprising that despite the need to increase the flexibility of water agreements in order to cope with water stress, riparian states find it difficult to do so (Magsig 2011: 339). In a context where states are often reluctant to implement rules that limit their sovereignty, many international water treaties are negotiated with good intentions but are ineffective in reality (Magsig 2011: 340).

This emphasis on sovereignty has constrained the way in which water security is conceived. In fact, to-date, there is no consensus around characterizing water as a shared natural resource (United Nations Environment Programme 1978). International water law does not address interdependencies beyond the geographic boundaries of basins (Leb \& Wouters 2013: 32). In other words, the global environment dimensions of water security are not integrated, even though ' $[\mathrm{s}]$ overeignty is no longer capable of providing the primary foundation for freshwater' law (Grey \& Garrick 2013: 44).

Existing literature recognizes that the main shortcoming of the current legal regime is 'shortsighted state-centrism' (Magsig 2015: 7). Yet what is considered to address the problem remains centered around notions that are closely related to sovereignty. This is in particular the case of the principle of common concern of humankind, reflected in the preambular language of several environmental treaties, such as the 1992 Convention on Biological Diversity but not in international water law. Common concern does not provide for the internationalization of resources but reflects at most a duty to cooperate concerning resources whose protection and use have transboundary dimensions. It is in view of the shortcomings of sovereignty that the need to consider water security as a matter of 'regional common concern' is proposed (Magsig 2009: 68; Magsig 2011: 320; Magsig 2020). Regional common concern emphasizes a general obligation to cooperate and is seen as a basis for overcoming the state-centrism of international law. At the same time, even this limited step is seen as potentially beyond what is acceptable to some states and therefore requiring a great deal of convincing, including an examination of the evolving nature of collective security and the role of international water law (Magsig 2011: 343; Magsig 2015: 139).

In a context where 'common concern' is seen as controversial, it is unsurprising that more cooperative notions are found to be impractical. The notion of 'common area' focuses on the 
equitable sharing of benefits from the exploitation of resources beyond the limits of national jurisdiction. However, it is driven by states' appetite for natural resources rather than the general interest of the international community in their protection (Magsig 2011: 340-1; Magsig 2015: 129). The notion of common heritage goes much further in terms of providing a regime of joint management for common resources. It has been applied to some natural resources beyond state sovereignty such as deep seabed minerals. There has been resistance to considering water as a common heritage of humankind, but this is slowly changing (Kpenou 2018). This is confirmed where interdependencies and the concept of 'one blue planet' are seen as calling for considering water security at the global scale and 'challenges the principle of sovereignty as the primary basis for achieving and sustaining water security' (Grey \& Garrick 2013: 45).

This is not to say that international law scholarship does not recognize interdependence of states in matters of transboundary water cooperation. In fact, it has been suggested that the duty to cooperate in the peaceful management of shared transboundary water resources may become an obligation erga omnes (Wouters, Vinogradov \& Magsig 2009: 132; Magsig 2011: 342). This obligation is owed to the international community as a whole. The progressive shift is thus in terms of the notion of sovereignty itself rather than towards new concepts. The underlying idea is to avoid seeing sovereignty as a stumbling block but rather to understand the duty to cooperate as a key element of sovereignty leading to the recognition of the concept of cooperative sovereignty. In this way, 'international law needs to pave the way for moving from an understanding of sovereignty as independence to one of sovereignty as interdependence' (Magsig 2020: 52).

The concept of hydro-solidarity underlies this understanding of water security. It seeks to shift the 'focus from competing national interests to common benefits' (Magsig 2015: 67). The main elements of this concept include motivating stakeholders and decision-makers to use broad information; designing organizational structures for finding compromises; making public participation socially acceptable; addressing social implications of resource use; and redressing the use of resources that damages the interest of other uses (Magsig 2015: 69). In terms of transboundary water, hydro-solidarity revolves around the idea of a cooperative community of users for 'managing shared international waters, based upon the river basin as the desired unit of management' (Wouters \& Ziganshina 2011: 199).

Overall, most of the international law literature on water security focuses on water in terms of international watercourses. It acknowledges the fact that water cannot be governed in isolation from the local to the international level (Magsig 2015: 3) but effectively fails to address water in its global dimensions, including issues related to climate change affecting, for instance, rainfall patterns around the world. Similarly, through its focus on rivers, the literature places overwhelming emphasis on surface water and consequently largely ignores groundwater. This is notwithstanding the fact that groundwater is an increasingly crucial dimension of water security in many countries (Albrecht et al. 2017) and is reflected in a first attempt by the International Law Commission (2008) to codify the law of transboundary aquifers. This confirms the increasing importance of groundwater but at the same time confirms the unwillingness of states to develop new bases for cooperation since the Draft Articles prepared by the International Law Commission offer states unqualified sovereignty over the portion of transboundary aquifers located within their territory (International Law Commission 2008: art. $3)$. On the whole, the literature remains centered on an understanding of water security that is embodied in sovereignty and not only fails to understand water as a commons from the local to the global level but also specifically rejects the relevance of principles already developed to address natural resources that are shared at the global level. This reflects a traditional understanding of international law and it is therefore not surprising that water security is often 
seen through the lens of dispute settlement, which contributes to the idea that international law can contribute to 'peace and security' through prevention and settlement of international disputes.

\section{B. OTHER BRANCHES OF INTERNATIONAL LAW}

The limited scope of international water law means that it does not engage effectively, for instance, with either protection aspects or concerns related to access to water. This has led to a broadening range of interventions that look at water security through developments in other areas of international law. This is in particular the case of international environmental law, international human rights law and international humanitarian law.

International environmental law is relevant for water security since its scope has included water from the outset, as reflected in Principle 2 of the Stockholm Declaration of the 1972 United Nations Conference on the Human Environment. This offers a broader approach than international water law for discussing water security as having arisen in the context of debates on environmental security (Magsig 2015: 18; see also Hulme 2009). Even if water management is not the primary objective of multilateral environmental agreements (MEAs), they are conceived around objectives that seek to integrate protection and use of environmental resources. This is what Leb \& Wouters (2013: 32) point towards when they assert that MEAs 'promote the maintenance and enhancement of ecosystem services that enhance water availability and quality for people and the environment'. International environmental law also adds content to the understanding of water security because it includes principles that go beyond the principles of international water law, which are predominantly focused on the use of water rather than its protection (Lê Phan \& Winkler 2016: 308). This is, for instance, the case of the precautionary principle that has become a central principle of international environmental law but is only reflected in international water law in some instruments such as the 1992 Helsinki Watercourses Convention.

In recent years, the link between the environment and water is made in large part through climate change, in keeping with the increasing focus of the environmental law literature on climate change. Climate change acts as one of the drivers of water insecurity (Honkonen 2017: 2). In this context, the literature emphasizes, for instance, the role that climate change law plays in preventing and adapting to natural disasters and achieving sustainable water security globally (Lê Phan \& Winkler 2016: 304). From a water security perspective, disruptions caused by climate change necessitate a certain degree of institutional and normative flexibility in freshwater governance, which 'would entail instruments and institutions that can adapt to changes and manage the level of uncertainty associated with the impacts of climate change' (Honkonen 2017: 9). In fact, some authors go as far as viewing water security as an answer to the limitations of the current environmental law paradigm. Larson (2020: 22) thus argues that water security can provide the basis for reorienting 'all of natural resource and environmental law and policy around achieving an acceptable quantity and quality of water with acceptable costs and risks'.

In the case of international human rights law, the link with water security has been made in the context of debates concerning the human right to water, for instance, in the case of the link between access to water, the right to water and individual water security (Wouters 2005: 175; Wouters, Vinogradov \& Magsig 2009: 115). This provides a way to frame (water) security concerns in terms of individual needs and entitlements rather than the aggregate perspective that is the hallmark of international water law literature. The discourse has progressively moved up to the point where Jepson, Wutich \& Harris (2020: 89) assert that 'a right to water needs to 
be redefined as «a right to water security»'. This proposed equivalence between the human right to water and water security confirms that the latter needs to be conceived in terms of its multiple layers, from the local to the global level, and from the individual to the level of the international community.

Water security is also addressed in the literature on international humanitarian law. The link is evident to the extent that international humanitarian law is at the crossroads between the traditional understanding of security and human security, from which discourses on environmental and water security have evolved. In fact, environmental security studies 'have underlined the role of water as the potential trigger for armed struggles' (Tignino 2010: 650). This is confirmed by the fact that water is both a source and target of armed conflict (Gleick 1993: 83; Gleick 2019: 2). At the same time, empirical studies suggest that 'states tend to cooperate rather than fight over shared water resources' (Koubi et al. 2013: 228). If water has not been the sole cause of armed conflicts in modern history, it has been used often as a military target or tool and conflicts over water use are numerous (Wouters 2010: 6). This is, for instance, the case when water supply infrastructure was targeted in the 1991 Persian Gulf War both in Kuwait and Iraq.

The broader lesson we learn from this review is that different branches of international law govern water security. This is confirmed by Lê Phan \& Winkler (2016: 295) who point out that individual water security in disaster settings is 'governed by a complex interplay of different branches of international law', including international humanitarian law, international criminal law, international environmental law, international water law, international refugee law, and international human rights law. Overall, the non-water law literature sheds some new light on the understanding of water security in international law. It also confirms that international water law literature has been largely framed in a relatively narrow context that does not reflect all the relevant variables.

It is probably unsurprising that international law scholars focus on understanding water security primarily in terms of how binding international law can ensure its realization. This implies that the focus remains largely on inter-state relations, even if non-state actors have become increasingly significant in the field over time. Scholarship is thus focused largely on examining the changes that have taken place in international law since the end of the Second World War and led to the development of a law of cooperation, while focusing on the central mission of ensuring peace and security. Scholarship recognizes that the concept of water security can be operationalized at different scales, but the focus of international water law scholars remains on the whole on transboundary watercourses and largely ignores the global dimensions of water. Other branches of international law such as environmental law take a broader view of the need for cooperation on issues of global concerns but even in this case, the starting point remains individual sovereign interests, as clearly reflected in the framing of commitments under the 2015 Paris Agreement around 'nationally determined contributions'.

\section{CONCLUSION}

Water security is recognized as an important concern in the international law literature. Debates have evolved through the broadening of the securitization discourse to encompass human security in the aftermath of the Cold War. International law scholarship on water security is based on an understanding of security as human security but it remains centered mostly on traditional notions of international law. Somewhat surprisingly given the attention paid to 'water wars' in popular media, there is relatively little emphasis on (military) security or on the concept of environmental security ('green wars'), which emerged in the 1990s to refer to 
the links between violent conflict and environmental degradation. One exception is the Middle East and North Africa, where early uses of the term water security explicitly focused on geopolitical security concerns (Cook \& Bakker 2012: 97-98). This is exemplified by international law's focus on dispute prevention and settlement and principles such as equitable and reasonable utilization.

At the same time, international law scholarship recognizes the broader dimensions of water security and the need to think beyond traditional approaches based on state centrism. Literature seeks to identify ways in which international law can transcend the barriers posed by sovereignty. In particular, it focuses on the notion of solidarity and principles aimed at fostering cooperation such as common concern of humankind, cooperative sovereignty and hydrosolidarity. However, the literature has not made any major contribution to this rethinking, which was already necessary at the turn of the century and has become urgent today in view of the water security crises linked to climate change and more broadly global environmental change. The scope for further research is immense since existing literature has only barely engaged with the challenges confronting states and non-state actors (to use the traditional international law distinction) as a result of changing weather patterns that affect rainfall and therefore freshwater availability.

Current literature is limited with regard to the overall framing of the concept of water security as well as specific issues. For instance, there is little engagement with groundwater, which is increasingly the primary source of water in many countries, or with ice (mountain and polar), rainfall and atmospheric water. Another common feature of this literature is an assumption about the normative value of water security. Overall, this analysis seems reductionist, and it fails to comprehensively engage with a number of other issues related to water security.

The relatively limited body of international law literature on water security adopts a traditional outlook on international water law that has remained focused for centuries on transboundary watercourses. This approach has hindered cross-fertilization among relevant branches of international law that integrate water. Such cross-fertilization is crucial because water security can be neither examined solely through the lens of watercourses nor considered separately from all the other directly connected areas. These areas include environmental law and human rights law, where some linkages have been made but without effective integration of the different fields.

The framing of water security in international law, which is centered on watercourses, is a helpful starting point but further development is imperative to broaden the field of water security. Recent decades have seen the rise of a number of new challenges, such as climate change, which has extended the scope of water regulation to the global level (global water cycle) and led to recognition of the transboundary dimensions of local water issues, such as the provision of sufficient safe domestic water, now covered under the human right to water. While international law scholarship has addressed some issues such as the human right to water, the broader water challenges linked to global environmental change remain largely outside the purview of the literature. Yet, this is where the most significant water security challenges of the future lie.

\section{Keywords}

Energy, environment, food, international law, rights, security, water

\section{References}

Albrecht, TR et al. 2017. Governing a shared hidden resource: a review of governance mechanisms for transboundary groundwater security. Water Security 2:43-56 
Allouche J, Middleton C, Gyawali D. 2019. The Water-Food-Energy Nexus-Power, Politics, and Justice. London: Routledge

Allouche J, Nicol A, Mehta L. 2011. Water security: towards the human securitization of water. Whitehead Journal of Diplomacy and International Relations 12:153-71

Appelgren B, Klohn W. 1997. Management of transboundary water resources for water security; principles, approaches and State practice. Natural Resources Forum 21(2):91-100

Belinskij A. 2015. Water-Energy-Food nexus within the framework of international water law. Water 7:5396-5415

Boute A. 2016. The water-energy-climate nexus under international law: A Central Asian perspective. Michigan Journal of Environmental \& Administrative Law 5(2):371-434

Brunnée J, Toope SJ. 1994. Environmental security and freshwater resources: a case of international ecosystems law. Yearbook of International Environmental law 5:41-76

Brunnée J, Toope SJ. 1997. Environmental security and freshwater resources: ecosystem regime building. American Journal of International Law 91(1):26-59

Burleson E. 2011. Water, climate, and energy security. Southwestern Journal of International Law 18(1):181-6

Carvalho KM, Minaverry CM. 2019. The Effects of International Agreements on Water Security: A Critical Study of the EU and MERCOSUR Approaches. Sustainable Consumption 285-305

Cook C, Bakker K. 2012. Water security: debating an emerging paradigm. Global Environmental Change 22(1):94-102

Cullet P, Bhullar L \& Koonan S. 2015. Inter-sectoral water allocation and conflicts: perspectives from Rajasthan. Economic and Political Weekly 50(34): 61-69

Daoudy M. 2008. Hydro-hegemony and international water law: laying claims to water right. Water Policy 10(2):89-102

Eckstein G. 2009. Water scarcity, conflict, and security in a climate change world: challenges and opportunities for international law and policy. Wisconsin International Law Journal 27:409-61

Gerlak AK, Mukhtarov F. 2015. 'Ways of knowing' water: integrated water resources management and water security as complementary discourses. International Environmental Agreements 15:257-72

Gleick PH. 1993. Water and conflict: fresh water resources and international security. International Security 18(1):79-112

Gleick PH. 2019. Water as a weapon and casualty of armed conflict: A review of recent waterrelated violence in Iraq, Syria, and Yemen. WIREs Water DOI: https://doi.org/10.1002/wat2.1351

Grey D, Garrick D. 2013. Water security, perceptions and politics: the context for international watercourse negotiations. In International Law and Freshwater - The Multiple Challenges, ed. LB de Chazournes, C Leb, M Tignino, pp. 37-47. Cheltenham: Edward Elgar

Grobicki A. 2016. Water-food-energy-climate: Strengthening the weak links in the Nexus. In The Water, Food, Energy and Climate Nexus - Challenges and an Agenda for Action. ed. F Dodds, J Bartram, pp. 127-37. Abingdon: Routledge 
Honkonen T. 2017. Water security and climate change: the need for adaptive governance. Potchefstroom Electronic Law Journal 20(1):DOI 10.17159/1727-3781/2017/v20n0a1651

Hulme K. 2009. Environmental security: implications for international law. Yearbook of International Environmental Law 19(1):3-26

International Court of Justice. 2010. Case Concerning Pulp Mills on the River Uruguay (Argentina v Uruguay). I.C.J. Reports 2010, p. 14

International Law Commission. 2008. Draft articles on the law of transboundary aquifers. Official Records of the General Assembly, Sixty-third Session, Supplement No. 10, U.N. Doc. A/63/10.

Iyer RR. 1999. Conflict resolution: three river treaties. Economic and Political Weekly 34(24): $1509-1518$

Jepson W, Wutich A, Harris LM. 2020. Water-security capabilities and the human right to water. In Water Politics - Governance, Justice and the Right to Water, ed. F Sultana, A Loftus, pp. 84-98. Abingdon, Oxon: Routledge

Johnson H. 2018. International Agricultural Law and Policy - A Rights-Based Approach to Food Security. Cheltenham: Edward Elgar

Keulertz M, Sowers J, Woertz E, Mohtar R. 2018. The water-energy-food nexus in arid regions - the politics of problemsheds. In Oxford Handbook of Water Politics and Policy, ed. K Conca, E Weinthal, pp. 167-96. Oxford: Oxford University Press

Koubi V, Spilker G, Böhmelt T, Bernauer T. 2013. Do natural resources matter for interstate and intrastate armed conflict?. Journal of Peace Research 51(2):227-243

Kpenou S. 2018. Fresh water as common heritage and a common concern of mankind. In Research Handbook on Freshwater Law and International Relations, ed. M Tignino, C Bréthaut, pp. 2-30. Cheltenham: Edward Elgar

Kuokkanen T. 2017. Water security and international law. Potchefstroom Electronic Law Journal 20(1): DOI 10.17159/1727-3781/2017/v20i0a1652

Larson RB. 2017. Water security. Northwestern University Law Review 112(2): 139-200

Larson RB. 2020. Just Add Water - Solving the World's Problems Using its Most Precious Resource. Oxford: Oxford University Press

Lê Phan H \& Winkler IT. 2016. Water security. In Research Handbook on Disasters and International Law, ed. SC Breau, KLH Samuel, pp. 295-318. Cheltenham: Edward Elgar

Leb C, Wouters P. 2013. The water security paradox and international law: securitization as an obstacle to achieving water security and the role of law in desecuritizing the world's most precious resource. In Water Security: Principles, Perspectives and Practices, ed. B Lankford, K Bakker, M Zeitoun, D Conway, pp. 26-46. Abingdon, Oxon: Routledge

Maduekwe NC, Young C-L. 2018. The impact of the water-energy nexus in realizing sustainable access to water and energy. In Ending Africa's Energy Deficit and the Law: Achieving Sustainable Energy for All in Africa, ed. Y Omorogbe, A Ordor, pp. 261-85. Oxford: Oxford University Press

Magsig B-O. 2009. Introducing an analytical framework for water security: a platform for the refinement of international water law. Journal of Water Law 20(2-3):61-9 
Magsig B-O. 2011. Overcoming state-centrism in international water law: 'regional common concern' as the normative foundation of water security. Göttingen Journal of International Law 3(1):317-44

Magsig B-O. 2012. Rising to the challenge of water security: international (water) law in need of refinement. International Journal of Sustainable Society 4(1-2):28-44

Magsig B-O. 2013. Water insecurity: a change agent for international water law reform. Global Dialogue 15(2):1-9

Magsig B-O. 2015. International Water Law and the Quest for Common Security. Abingdon, Oxon: Routledge

Magsig B-O. 2017. Water security as an evolving paradigm: local, national, regional and global considerations. In Routledge Handbook of Water Law and Policy, ed. A Rieu-Clarke, AA Allan, S Hendry, pp. 382-94. London: Routledge

Magsig B-O. 2020. Water security: A litmus test for international law. Review of European Comparative \& International Environmental Law 29(1):44-55

Mahayni B. 2013. Producing crisis: hegemonic debates, mediations and representations of water scarcity, In Contemporary Water Governance in the Global South - Scarcity, Marketization and Participation, ed. LM Harris, JA Goldin, C Sneddon, pp. 35-44. Abingdon, Oxon: Routledge

Mekonnen DZ. 2010. The Nile Basin Cooperative Framework Agreement negotiations and the adoption of a 'water security' paradigm: flight into obscurity or a logical cul-de-sac?. European Journal of International Law 21(2):421-40

Permanent Court of International Justice. 1929. Territorial jurisdiction of the International Commission of the River Oder, Judgment No 16, Series A, No. 23, p. 27

Rieu-Clarke A. 2010. The role of treaties in building international watercourse regimes: a legal perspective on existing knowledge. Water Policy 12(6):822-31

Scholtz W. 2009. Collective (environmental) security: the yeast for the refinement of international law. Yearbook of International Environmental Law 19(1):135-62

Sultana F, Loftus A. 2020. The right to water in a global context: challenges and transformations in water politics. In Water Politics - Governance, Justice and the Right to Water, ed. F Sultana, A Loftus, pp. 1-14. London: Routledge

Tarlock AD. 2008. Water security, fear mitigation and international water law. Hamline Law Review 31(3):703-28

Tarlock D, Wouters P. 2010. Reframing the water security dialogue. Journal of Water Law 20(3):53-60

Tignino M. 2010. Water, international peace, and security. International Review of the Red Cross 92/879:647-74

United Nations. 2019. The human rights to safe drinking water and sanitation. General Assembly Resolution 74/141, U.N. Doc. A/RES/74/141

United Nations Environment Programme. 1978. Environmental law guidelines and principles on shared natural resources, U.N. Doc. UNEP/GC.6/17

Weinthal E, Vengosh A, Neville KJ. 2018. The nexus of energy and water quality. In Oxford Handbook of Water Politics and Policy, ed. K Conca, E Weinthal, pp. 197-226. Oxford: Oxford University Press 
World Water Forum. 2000. Ministerial declaration of The Hague on water security in the 21st century

$<$ http://www.worldwatercouncil.org/fileadmin/world_water_council/documents/world_water _forum_2/The_Hague_Declaration.pdf $>$

Wouters P. 2000. The relevance and role of water law in the sustainable development of freshwater: from 'hydrosovereignty' to 'hydrosolidarity'. Water International 25(2):202-7

Wouters P. 2005. Water security: what role for international water law. In Human and Environmental Security: An Agenda for Change, ed. F Dodds, T Pippard, pp. 166-81. London: Earthscan

Wouters P. 2010. Water security: global, regional and local challenges. London: Institute for Public Policy Research

Wouters P. 2014. 'Dynamic cooperation' - the evolution of transboundary water cooperation. In Water and the Law - Towards Sustainability, ed. M Kidd et al., pp. 13-65. Cheltenham: Edward Elgar

Wouters P. 2015. Addressing water security challenges: the international law 'duty to cooperate' as a limit on absolute state sovereignty. In A History of Water, Volume 2: Sovereignty and International Water Law, ed. T Tvedt, O McIntyre, TK Woldetsadik, pp. 33454. London: IB Tauris

Wouters P, Moynihan R. 2012. Water security - Legal frameworks and the UN Watercourses Convention. In The UN Watercourses Convention in Force: Strengthening International Law for Transboundary Water Management, ed. FR Loures, A Rieu-Clarke, pp. 336-51. London: Earthscan

Wouters P, Vinogradov S, Magsig B-O. 2009. Water security, hydrosolidarity, and international law: a river runs through it.... Yearbook of International Environmental Law 19(1):97-134

Wouters P, Ziganshina D. 2011. Tackling the global water crisis: unlocking international law as fundamental to the peaceful management of the world's shared transboundary waters introducing the $\mathrm{H} 2 \mathrm{O}$ paradigm. In Water Resources Planning and Management, ed. RQ Grafton, K Hussey, pp. 175-229. Cambridge: Cambridge University Press

Zawahri NA. 2008. Designing river commissions to implement treaties and manage water disputes: the story of the Joint Water Committee and Permanent Indus Commission. Water International 33(4): 464-474

Ziganshina D. 2014. Promoting Transboundary Water Security in the Aral Sea Basin through International Law. Leiden: Brill 